\title{
UMBATRA
}

\section{Metode Penulisan Naskah Kolektif: Di Balik Pertunjukan Teater "Tanah Ode Kampung Kami"}

\author{
Iman Soleh ${ }^{1}$, Mahesa El Gasani ${ }^{2}$, Mazeinda Al Biruni ${ }^{3}$, Tari Purwanti ${ }^{4}$ \\ ${ }^{1}$ Program Studi Seni Teaater, Institut Seni Budaya Indonesia \\ solehiman@yahoo.com \\ 2 Komunitas Celah-Celah Langit (CCL) Bandung \\ elgasanimahesa@gmail.com \\ 3 Program Studi Bahasa dan Sastra Indonesia, Universitas Pendidikan Indonesia \\ mazeinda@upi.edu \\ ${ }^{4}$ Program Studi Pascasarjana Antropologi, Universitas Gadjah Mada \\ tari.purwanti01@gmail.com
}

\begin{abstract}
The creation of a play entitled "Tanah Ode Kampung Kami" have several stages, starting from determining the issue and the ideas, conducting research, implementing the method of collective writing text, and finally becomes a show. The research process is a way of organizing and understanding the main problem of a play, i.e. the land, so it would be able to be implemented as a drama script collectively in theatrical performances. Collective text aims to make actors and directors have the same perception of a predetermined theme. This study uses a qualitative research design with data collection methods in the form of observations and interviews. The conclusion of this study is that the collective text method used in the "Tanah Ode Kampung Kami" script is used to harmonize the ideas that were built together so that it becomes a complete text which is the result of collaborative thinking between the elements involved in the process of making the script.
\end{abstract}

Keywords: research process, text collective method, theater play

\begin{abstract}
Abstrak
Penciptaan teater "Tanah Ode Kampung Kami" memiliki beberapa tahapan, dimulai dari penentuan isu dan gagasan, melakukan riset, menerapkan metode penulisan naskah kolektif hingga akhirnya menjadi sebuah pertunjukan. Proses riset merupakan cara sutradara dan aktor memahami permasalahan yang menjadi ide pokok, yaitu tanah, hingga bisa diimplementasikan sebagai naskah drama secara kolektif di dalam pertunjukan teater. Naskah kolektif bertujuan agar aktor dan sutradara memiliki persepsi yang sama mengenai tema yang sudah ditentukan. Metode yang digunakan dalam penelitian ini menggunakan desain penelitian kualitatif dengan metode pengumpulan data berupa observasi dan wawancara. Simpulan dari penelitian ini adalah bahwa metode naskah kolektif yang digunakan dalam naskah "Tanah Ode Kampung
\end{abstract}


Kami” digunakan untuk menyelaraskan gagasan yang dibangun secara bersama-sama, sehingga menjadi sebuah naskah utuh yang merupakan hasil kolaborasi pemikiran antar unsur yang terlibat di dalam proses pembuatan naskah.

Kata kunci: proses riset, metode naskah kolektif, teater

\section{Pendahuluan}

Seni dalam wacana antropologi kontemporer merupakan utopia mikro yang terbungkus secara artistik (Blanes, et al., 2016). Seni juga merupakan fenomena sosial yang melibatkan perilaku yang dapat diamati dan dapat memengaruhi orang lain (Hayes, 1911). Salah satu bentuk seni yang seringkali dianggap mewakili definisi ini adalah seni teater. Pertunjukan teater adalah upaya pengungkapan ekspresi untuk menyuarakan berbagai permasalahan aktual di masyarakat, sehingga menjadi gerakan dan metode sosial untuk memberdayakan masyarakat (Gasani, 2019).

Di dalam pendekatan kontekstual, kesenian teater tetap dapat dilihat sebagai teks, yang penting untuk dianalisis dalam konteks berbagai kebudayaan dan fenomena di masyarakat. Biasanya analisis ini menghasilkan gambaran hubungan sebab-akibat, hubungan fungsional atau hubungan saling ketergantungan antara teks dan konteksnya (Ahimsaputra, 2002).

Penyesuaian teks dengan konteks kebudayaan setempat melahirkan perbedaan yang menjadi ciri khas tiap kelompok teater. Ciri khas tersebut tidak hanya dapat ditemukan pada bentuk, artistik, bunyi, dan gerak, tetapi juga dapat ditemukan pada naskah yang dipentaskan.

Membahas metode naskah kolektif dalam pembuatan naskah teater, artinya membicarakan gagasan yang dibangun bersama-sama dalam sebuah kerja sama penyusunan naskah pertunjukan. Latar belakang yang berbeda-beda dari setiap aktor yang terlibat dalam penyusunan naskah tersebut, misal (kuli bangunan, pengamen jalanan, juru masak di warung nasi, anak sekolah, dll), menjadikan sebuah naskah pertunjukan memiliki keunikan tersendiri dengan warna khasnya. Naskah yang disusun secara kolaboratif menjadi tidak kaku, dan menjadi lebih hidup untuk dipentaskan.

Setiap aktor tidak terikat dalam identitas ruang-waktu terhadap satu tokoh yang ia perankan, melainkan mereka dapat melakukan pendalaman terhadap tubuh, pola panggung, artistik, dan dari segala aspek lain yang ada dalam pertunjukan. Kelebihan dari setiap individu yang memerankan satu tokoh dapat lebih muncul dalam pertunjukan. Berangkat dari kelebihan itulah, para aktor dituntut untuk lebih mengedepankan kerja sama dalam membangun pertunjukan.

Boal (2008) dalam "Theatre of The Oppressed" menjelaskan bahwa teater yang diciptakan oleh masyarakat jauh lebih ketat daripada seni lainnya. Hal itu karena adanya kontak langsung dengan publik yang memunculkan kekuatan yang lebih besar untuk meyakinkan pemirsanya. Hal inilah yang mendasari kelompok teater menciptakan karya yang melibatkan masyarakat.

Seni teater bersifat terbuka dengan pilihan dan tujuannya. Oleh karena itu setiap kelompok teater akan memiliki keunikannya masing-masing. Penelitian mengenai teater dari sudut pandang Antropologi lebih banyak membahas tentang teater sebagai penampilan (performance). Misal penelitian Fons Sastre (2019) tentang aktor teater dalam analisis Antropologi Teater (Anthropology of Theatre). Lalu, penelitian Fabian (1999) tentang teater dalam bingkai kultural; yang menganalisis keterkaitan antara latar belakang budaya dan penampilan aktor. Penelitian Knight dan Stewart (2016), Conquergood (1985) dan Enria (2016) membahas kajian etnografi dalam pertunjukan teater. Penelitian mengenai metode penulisan naskah teater dalam kajian Antropologi masih luput 
dari pengamatan para peneliti.

Komunitas Celah-Celah Langit, sebagai salah satu komunitas teater di Kota Bandung juga memiliki keunikan tersendiri. Komunitas ini acap kali mengangkat berbagai persoalan di masyarakat sebagai gagasan utama konten pertunjukan mereka. Misal, pertunjukan teater berjudul "Air" pada tahun 2006, diilhami oleh respons masyarakat dan seniman pada UU Nomor 7 Tahun 2004 mengenai sumber daya air. Konten pertunjukan merupakan upaya untuk menyuarakan kekhawatiran masyarakat atas penguasaan sumber mata air oleh korporat. Pertunjukan berjudul "Petani Sawah di Kepalamu” tahun 2018 juga merupakan ekspresi kecemasan pada situasi krisis ketahanan pangan, yang ditandai dengan berkurangnya lahan sawah, ladang, dan kemampuan bertani sejumlah anak muda.

Pertunjukan teater yang dibahas dalam artikel ini berjudul "Tanah Ode Kampung Kami". Konten pertunjukan ini terinspirasi oleh keresahan sutradara dan aktor terkait kasus Mesuji di Lampung tahun 2011, kasus Tangkuban Perahu Lembang tahun 2012, dan beberapa kasus permasalahan tanah yang sering kali terjadi di Indonesia. Di Komunitas CCL Bandung, konsep kolektif bukan hanya pada penataan artistik, tetapi hingga konten pertunjukan teater yang secara kolektif dan intens tersusun sejak proses penulisan teksnya.

Di samping mengolah kemampuan menari (dancing), bernyanyi (singing), dan bermain peran (acting), setiap aktor di Komunitas CCL Bandung diwajibkan pula untuk berlatih menulis naskah sendiri. Naskah yang telah dirumuskan dan ditulis bersama-sama oleh para aktor disebut sebagai naskah kolektif. Metode naskah kolektif ini merupakan praktik yang dilakukan oleh para aktor untuk meningkatkan kemampuan mereka dalam menulis (writing). Naskah kolektif ini dibuat bersama-sama oleh para aktor di dalam satu tema, kemudian diarahkan oleh sutradara untuk membentuk suatu naskah. Metode ini diterapkan dalam beberapa pertunjukan yang dilakukan Komunitas CCL Bandung, salah satunya adalah "Tanah Ode Kampung Kami”. Pertunjukan ini mengemukakan permasalahan seperti sengketa tanah, pengelolaan lahan kurang baik, dan petani sebagai pengelola lahan yang tidak begitu diperhatikan. Tulisan ini akan membahas proses pembuatan naskah kolektif yang digunakan dalam metode penulisan naskah pada pertunjukan teater "Tanah Ode Kampung Kami” yang diadakan oleh Komunitas CCL Bandung.

\section{Kajian Pustaka}

\section{Seni dan Kesenian}

Seni merupakan segala ekspresi hasrat manusia akan keindahan. Seni secara umum terbagi menjadi dua kelompok, yaitu: (a) seni rupa, atau kesenian yang dinikmati oleh manusia dengan mata; dan (b) seni suara, atau kesenian yang dinikmati oleh manusia dengan telinga. Salah satu bentuk kesenian yang meliputi keseluruhan antara seni rupa dan seni suara adalah teater, karena di dalamnya mengandung unsur-unsur dari seni lukis, seni rias, seni musik, seni sastra, dan seni tari semua diintegrasikan menjadi suatu kesatuan (Koentjaraningrat, 2015). Meskipun pada dasarnya manusia bebas dan menginginkan kebebasan sesuai dengan keinginannya, tetapi setiap karya seni atau kebudayaan lahir dalam konteks tempat dan waktu tertentu, dan sedikit-banyak mencerminkan aturan dan cara hidup dari masyarakat tempat seni itu diciptakan (Sumardjo, 2001).

Seni menempati posisi khusus dalam kehidupan masyarakat dan terwujud dalam praktik sosial budaya, yang dilihat menggunakan nilai estetika. Merujuk pada teori Turner (1979), seni berada pada posisi "liminal" antara masyarakat dan budaya. Keindahan seni tidak hanya didapatkan dari pengalaman visual semata, melainkan cenderung didapatkan dari pengalaman batiniah seseorang yang berkaitan dengan pengalaman estetis dengan nilai-nilai mistis ataupun religius (Iryanti, 2016).

Pembahasan antara seni dan antropologi tidak hanya mempromosikan dan mengarah 
pada kolaborasi yang harmonis dan estetis sebagaimana definisi seni di atas. Di sisi lain, seni dapat pula memprovokasi "perlawanan", kritik, dan kontestasi yang dikomunikasikan dalam bentuk-bentuk kesenian yang kemudian menyoroti perbedaan antara kedua bidang ini serta mempertimbangkan aspek politik yang ada (Grimshaw dan Ravetz, 2015; Knight dan Stewart, 2016). Hal ini sebagaimana yang terdapat dalam penelitian yang dilakukan oleh Yalouri mengenai seni visual dalam metafisika krisis Yunani (Yalouri, 2016). Namun pendapat tersebut ditentang oleh Jelinek yang menganggap bahwa kerja antropolog dalam melihat seni terkesan tidak menghargai seniman dan tidak melihat seni dari cara pandang seniman (Jelinek, 2016).

Di luar perbedaan sudut pandang tersebut, karya seni dimasukkan ke dalam wacana pemberdayaan dan advokasi, menentang kemunculan, pertumbuhan, dan intensifikasi jaringan hubungan sosial antara lembaga dan individu, dalam masyarakat tertentu dan lintas budaya. Keterlibatan individu dengan karya seni diperkuat oleh parameter sosial bidang seni transaksional representasi visual. Pengetahuan sebelumnya tentang makna dan status sebuah karya seni mendorong interpretasi tertentu dan memengaruhi estetika pengalaman (Maihoub, 2015; John, 1992).

\section{Teater}

Teater merupakan sebuah bentuk kesenian yang dapat digunakan untuk bersuara dan berbicara kepada masyarakat. Kritik menjadi sangat dekat dengan teater, baik itu halus, rahasia, maupun yang menohok dan frontal. Teater adalah alat untuk berbicara kepada publik dan kekuasaan. Di dalam teater tradisi, fungsi teater sebagai media kritik sosial merupakan sesuatu yang dianggap wajar. Biasanya kritik akan diterima dengan baik apabila kritik itu disampaikan dengan ramah, santun, terselubung, sehingga sangat tepat apabila dilakukan melalui humor (Gasani, 2019).

Teater terdiri dari segala jenis pertunjukan yang mengandalkan tubuh dan sukma manusia sebagai media dan mengusung empat un- sur dasar yang terdiri dari ide dasar, pemain, tempat permainan, dan penonton (Anirun, 2002). Teater terbagi menjadi tiga golongan, yakni teater sastra, teater eskapis, dan teater sosial (Dolman Jr dan Knoub dalam Anirun, 2002). Jika dilihat dalam arti luas, teater merupakan tontonan yang dipertunjukkan di depan banyak orang. Namun, dalam arti sempit teater merupakan drama, kisah hidup, dan kehidupan yang diceritakan di atas panggung, disaksikan oleh orang banyak melalui penggabungan beberapa media, yaitu: percakapan, gerak dan laku, dengan atau tanpa dekorasi (layar dan sebagainya), didasarkan pada naskah yang tertulis (hasil seni karya) dengan atau tanpa musik, nyanyian, dan tarian (Harymawan, 1988).

Bahasa yang digunakan dalam pertunjukan teater berbeda dengan bahasa yang digunakan dalam kehidupan sehari-hari. Laku di dalam teater menyatakan bahwa peranan bahasa di dalam teater cukup penting, sehingga bahasa harus dihidupkan oleh para pemain di atas panggung (Harymawan, 1988; Fabian, 1999).

Pertunjukan teater dalam pandangan Antropologi dapat saja berubah menjadi pertunjukan politik yang dapat menciptakan konteks pemikiran bagi para antropolog untuk mengeksplorasi bagaimana orang merefleksikan kemanusiaan, sosialitas, perubahan, dan harapan mereka untuk masa depan. Pertunjukan-pertunjukan politik yang dihadirkan dalam koleksi tersebut disatukan sebagai contoh etnografis dan sebagai proposisi analitis. Pertunjukan ini menyatukan penonton dan pemain dalam sebuah pengalaman kontemplatif, di dalam ruang yang dibagikan dengan membentuk pemahaman baru dan umum tentang dunia (Aaron, 2018).

\section{Naskah Pertunjukan}

Beberapa aktivitas dalam sebuah pementasan drama di antaranya adalah mempelajari naskah pertunjukan, mengingat dialog, mempelajari karakteristik tokoh, mempersiapkan pertunjukan dan melakukan pementasan (Hulse dan Owens, 2019). Memainkan sebuah peran di atas panggung adalah sebuah 
permainan canggih yang berbelit-belit, yang dilakukan untuk merealisasikan khayalan, kepura-puraan, dan meniru ide dalam sebuah naskah (Emenike, 2017). Naskah merupakan sebuah gagasan yang diuraikan dalam bentuk teks menjadi cerita yang di dalamnya terdapat berbagai unsur, di antaranya unsur tema, peran, cerita, dan unsur bentuk dan gaya. Naskah merupakan penuntun seorang sutradara dalam membuat karya teater, demikian juga dengan aktor dalam mewujudkan perannya.

Di dalam mempersiapkan sebuah pertunjukan drama, naskah lakon merupakan tahapan pertama yang berperan sebelum sampai ke tangan sutradara dan para aktor (Anirun, 2002). Keterhubungan sutradara dengan naskah sangatlah penting. Naskah lakon bagaikan partitur musik di tangan dirigen, begitu pula aktor yang merupakan seorang seniman untuk mewujudkan peran lakon atau sosok pelaku dalam sebuah lakon ke dalam realita seni pertunjukan (Anirun, 2002). Hal ini yang menjadi dasar keterhubungan aktor dengan sutradara di dalam naskah kolektif.

Penulis lakon menuangkan ide-ide ceritanya menurut dorongan dalam visi artistik, dengan berbagai kecenderungan bentuk dan gaya (Anirun 2002). Penulisan naskah di dalam pertunjukan teater "Tanah Ode Kampung Kami" melibatkan aktor yang dibimbing dan diarahkan dalam tema yang sama oleh sutradara sehingga tidak keluar dari ruang lingkup yang telah disepakati. Penulisan naskah kolektif dalam pertunjukan ini merupakan sebuah proses penghayatan dari keresahan bersama dan riset yang telah dilakukan hingga menemukan hubungan batin antara aktor, naskah dan sutradara.

Di dalam pertunjukan teater, bahasa merupakan salah satu unsur penguat terbentuknya alur, dan memberikan perspektif kepada penonton, mengenalkan bahasa asing, serta menyampaikan nilai-nilai kultural (Elam, 1977; Miccoli, 2003; Gill, 2013; Hulse dan Owens, 2019). Berangkat melalui perspektif tradisi lisan, mantra-mantra dan naskah drama dalam pertunjukan, memiliki kedekatan yang kuat dengan kebudayaan masyarakat
(O’Donnell, 2017; Alifirevic dan Alifirević, 2017; Raquel, 2011), sehingga para penulis bekerjasama dengan para pemain.

Penyusunan naskah dalam konsep naskah kolektif mengambil pandangan dari teori Todorov (1985). Teori tersebut membahas satuan sintaksis naratif yang menggabungkan antara satu sekuen dengan sekuen yang lain. Konsep tersebut diterapkan dalam penyusunan naskah secara kolektif, yang mentransformasi sekuen menjadi satuan tema atau topik. Satuan tersebut kemudian digunakan dalam pertunjukan sebagai adegan-adegan yang diisi oleh dialog-dialog para aktor dalam menanggapi permasalahan (Gualdron dan Castillo, 2018; Gill, 2013; Butcher et al., 2017). Titik tekan atas penggunaan teori Todorov ini, terletak dari penggunaan dialog-dialog dalam naskah teater. Naskah yang dibangun oleh kalimat-kalimat, merupakan bagian dari sekuen-sekuen yang ukurannya lebih besar dari kalimat biasa. Garis besarnya, sekuen mengambil lingkaran-lingkaran dalam kalimat dan secara intuitif dapat ditemukan oleh pembaca atau apresiator.

\section{Aktor dalam Teater}

Sebuah penampilan drama teater tidak hanya menyangkut persoalan memainkan peran, tetapi juga sebagai tindakan moral (Conquergood, 1985), representasi situasi sosial (Fons Sastre, 2019), ideologi (Lemon, 2004), pertukaran dan implementasi pengetahuan (Schneider et al., 2014; Enria, 2016), sebagai institusi sosial yang membawa dan menyebarkan sistem simbolik sentral dari tradisi budaya (Aaron, 2018; Goodlander, 2012), dan penciptaan makna budaya dalam bingkai "performance" (penampilan) (Beeman, 2017).

Aktor atau seniman adalah salah satu unsur penting dalam sebuah pementasan teater. Mereka inilah yang bertanggung jawab dalam mewujudkan peran yang terdapat dalam sebuah ide cerita dari naskah yang dipentaskan. Keberhasilan seorang aktor dilihat dari beberapa kriteria, yaitu: (a) tahap memerankan, artinya seorang aktor harus dapat memerankan tokoh yang ada di dalam naskah; (b) tahap se- 
bagai, artinya bagaimana seorang aktor bertindak sebagai tokoh yang diperankan; (c) tahap menjadi, pada tahap ini aktor menjadi satu dengan tokoh yang diperankan sehingga ia tidak lagi menjadi dirinya sendiri melainkan menjadi tokoh atau karakter yang sedang diperankannya; (d) tahap adalah, pada tahap ini identitas aktor tidak lagi sebagai pemain peran, namun sebagai karakter yang diperankan, dan (e) tahap sempurna, yang berarti aktor telah melepas segala atribut dirinya dan kini ia telah memiliki identitas baru yakni sebagai karakter yang terdapat di dalam naskah yang sedang ia mainkan (Doyin, 2001).

Seorang aktor tidak terlepas dari persoalan dimensi ruang, tempat ia memainkan perannya. Ruang diinterpretasikan sebagai lingkungan yang dipersepsikan ataupun area geografis yang memiliki hubungan secara personal, sehingga terdapat interaksi psikologis antara individu (dalam hal ini aktor) dengan lokasi ataupun latar tempat dalam penampilan teater yang berbasis lokasi (place-based performance) (MacKey, 2007; Wessels, 2014). Di dalam kontestasi di atas panggung, bermain peran bagi seorang aktor berarti membawa sesuatu yang tidak "nyata" ke dalam kehidupan nyata untuk menyampaikan pengalaman, perasaan dan situasi yang terjadi kepada audiens.

Seorang aktor dituntut untuk dapat menempatkan dirinya sebagai tokoh yang diperankannya, dengan mengomunikasikan rasa, tingkah laku, bahasa tubuh dan apapun yang dipahaminya dari tokoh yang diperankannya, serta dituntut memiliki kemampuan untuk "mengalami" tokoh yang diperankannya, melalui suara (vokal) dan gerak tubuh (de Goulart dan Vilanova, 2011; Mauro, 2017; Broth, 2011). Hal ini bertujuan menghadirkan timbal balik antara aktor dengan penonton (Broth, 2011; Waterson, 2010).

Suharianto (1982) mengatakan bahwa menerjemahkan dan menghidupkan naskah cerita adalah tugas seorang aktor. Hal ini menjadi dasar emosional yang dapat menjamin kuan- titas dan kualitas pementasan (Mauro, 2017) dalam berbagai perbedaan peran dan situasi. Mempelajari pertunjukan dalam berbagai latar teater dan media lintas budaya tidak hanya mengungkapkan sesuatu tentang budaya secara ekspresif, tetapi juga kehidupan sosial budaya dalam permainan peran (Wilkinson-Weber, 2012).

\section{Metode}

Metode yang digunakan dalam penelitian ini menggunakan desain penelitian kualitatif dengan metode pengumpulan data berupa observasi dan wawancara untuk mendapatkan informasi yang utuh dan mendalam tentang penciptaan teater "Tanah Ode Kampung Kami". Di dalam observasi, peneliti mengamati dan terlibat langsung dengan aktivitas Komunitas CCL Bandung sehingga mendapatkan informasi yang utuh mengenai pementasan teater "Tanah Ode Kampung Kami". Penulis juga membangun rapport (menjalin proses yang baik dengan objek yang diteliti sehingga tidak ada lagi dinding pemisah). Peneliti juga ikut terlibat dalam proses penciptaan naskah teater yang diawali dari proses observasi terhadap masyarakat petani Lembang, Kab. Bandung, proses wawancara, hingga perumusan naskah kolektif.

Teknik wawancara yang dilakukan dalam penelitian ini dilakukan untuk mendapatkan informasi mendalam mengenai penciptaan teater "Tanah Ode Kampung Kami" kepada para aktor, seniman, dan sutradara untuk mendapatkan informasi yang utuh terkait penciptaan teater, dan secara khusus untuk mengkaji metode penulisan naskah kolektif yang menjadi ciri khas pertunjukan teater dari Komunitas CCL Bandung. Alat yang digunakan berupa alat perekam (audio recorder) dan kamera. Kedua alat ini digunakan untuk mengabadikan informasi yang disampaikan oleh informan-informan yang terlibat.

Data yang telah didapatkan kemudian dianalisis dan dikelompokkan berdasarkan beberapa kategori yang telah ditentukan, yaitu berupa 
ide dan gagasan, desain pertunjukan, aktor dan sutradara, dan metode penulisan naskah. Triangulasi data dilakukan untuk mengkaji dan menguji kembali validitas informasi yang telah didapatkan dari berbagai sumber.

\section{Hasil dan Pembahasan}

\section{Penciptaan Teater: dari Gagasan hingga Pertunjukan}

Proses penciptaan teater memerlukan beberapa tahapan hingga menjadi sebuah pertunjukan. Hal ini berlaku pada proses penciptaan teater “Tanah Ode Kampung Kami” yang mengusung masalah lingkungan dan petani. Pertunjukannya seringkali disebut sebagai upaya pemberdayaan masyarakat.

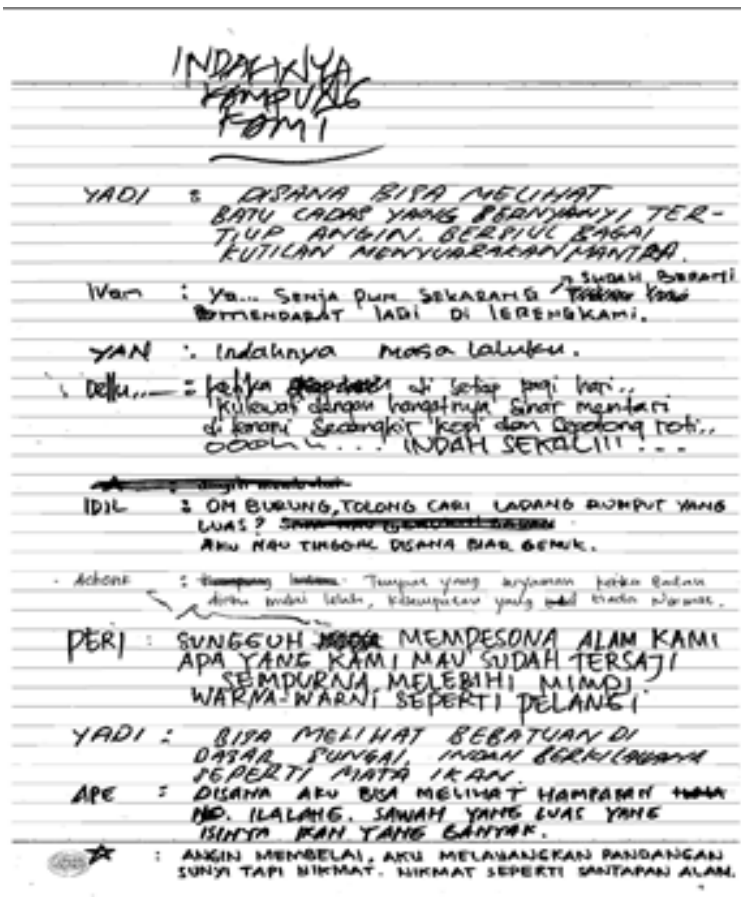

Gambar 1. Penulisan Naskah

Sumber: Dokumentasi Peneliti

Secara umum, tahapan-tahapan yang dapat diuraikan dalam penciptaan teater ini dimulai dari menentukan gagasan, pembuatan naskah yang dilakukan oleh para aktor, penafsiran adegan oleh sutradara, penggunaan sketsa sebagai dasar tafsir adegan, pengaturan artistik, pertunjukan teater dan evaluasi.

\section{Menentukan Gagasan}

Permasalahan tanah yang terjadi di negeri ini menjadi pemicu terciptanya sebuah karya sastra berjudul "Tanah Ode Kampung Kami”. Wacana dalam pertunjukan didiskusikan secara bersama-sama dengan para aktor dan sutradara sampai akhirnya menemukan titik gagasan kolektif. Berdasarkan kesepakatan bersama inilah ditemukan sebuah gagasan yang berbicara tentang tanah, yaitu mengangkat persoalan sengketa tanah; penggusuran, hak-hak petani yang tidak diperhatikan, dijualnya tanah-tanah desa penggusuran, dan alih fungsi lahan menjadi tempat pariwisata. Cara yang dilakukan untuk menguatkan gagasan tersebut dengan mengumpulkan data yang berhubungan dengan masalah tanah (lihat Gambar 1).

Data untuk membuat naskah ini diperoleh dari wawancara bersama petani, tulisan di media, informasi dari televisi dan internet, serta diskusi yang dilakukan antara aktor, sutradara, petani, dan berbagai pihak lain tentang lingkungan hidup, ketahanan pangan, penyerobotan lahan, petani, batas wilayah, peperangan, dan UUD Agraria. Salah satu sumber riset lapangan berlokasi di Lembang, Kabupaten Bandung Barat, Jawa Barat.

\section{Pembuatan Naskah}

Langkah selanjutnya dalam penciptaan sebuah pertunjukan yaitu pembuatan naskah yang dilakukan oleh sutradara dan aktor. Langkah tersebut dilakukan setelah sutradara dan aktor merasa data yang didapatkan sudah cukup. Proses pembuatan naskah berangkat dari sebuah pengalaman dalam menulis dialog. Hal tersebut semacam tanya-jawab dengan imajinasi yang tidak terbatas. Kegiatan menulis percakapan atau yang lebih dikenal sebagai dialog ini dilakukan atas dasar gagasan yang ditentukan bersama. Kesadaran para penulis (yang sekaligus pemain) dibangun berdasarkan pengalaman dan informasi yang mereka dapatkan. Pada teater "Tanah Ode Kampung Kami”, pemain menyampaikan pendapatnya mengenai permasalahan tanah.

Banyak hal tidak terduga ketika mereka menuliskannya hingga menghasilkan tulisan yang begitu liar dan tajam. Perbedaan latar be- 
lakang pemain telah memberi kontribusi teks yang penuh warna dan meluncur dengan tidak terduga. Para penulis bekerjasama dengan para pemain. Proses penulisan ini dilakukan melalui chatting di Facebook dan SMS tanya-jawab yang mengalir dari satu penulis ke penulis lainnya (para pemain).

Para pemain mendefinisikan tujuan karakter, menentukan objektivitas karakter, serta maksud dan tujuan penulisan naskah. Kalimat-kalimat begitu liar-dalam arti ekspresif dan imajinatif, mengalir dari para pemain yang menuliskan sendiri dialognya. Teknik penulisan dengan metode percakapan telah membantu para pemain belajar menulis, memahami isi, menghayati kalimat, memahami struktur dramatik, dan yang paling menarik adalah aktor ikut menganalisis serta menentukan gagasan sebagai tema pertunjukan. Hal ini membantu melatih pemain sehingga mereka mampu mengembangkan potensi, dan maksud berteater. Pengembangan skenario dilakukan dengan mempelajari persoalan dari berbagai sumber, baik buku, media cetak, atau mungkin televisi.

Spontanitas saat menulis menjadi prioritas sehingga penulis terbiasa menguasai kalimatnya sendiri. Wawasan menulis turut membantu pada pencapaian struktur adegan dan pengembangan naskah. Oleh karena keterbukaan ruang dalam merumuskan naskah secara bersama ini, sehingga penulis menjadi tidak khawatir jika naskah tidak linear sebagai sebuah naskah cerita drama. Pemain harus mengembangkan dirinya dalam berimajinasi. Semakin luas imajinasi yang dimiliki oleh para pemain, maka naskah yang dihasilkan semakin tidak terduga. Tulisan ini yang kelak menjadi fragmen-fragmen kecil yang digunakan untuk menyusun naskah teater.

Setiap adegan untuk pertunjukan teater dibuat dengan sederhana dan ditulis bercabang-cabang seperti ranting pohon (lihat Gambar 2). Para pemain mengembangkan sendiri kalimat yang mereka pilih untuk dijadikan adegan. Sebagai contoh, inilah salah satu alur pembentukan naskah adegan yang dimulai dari kata tanah:

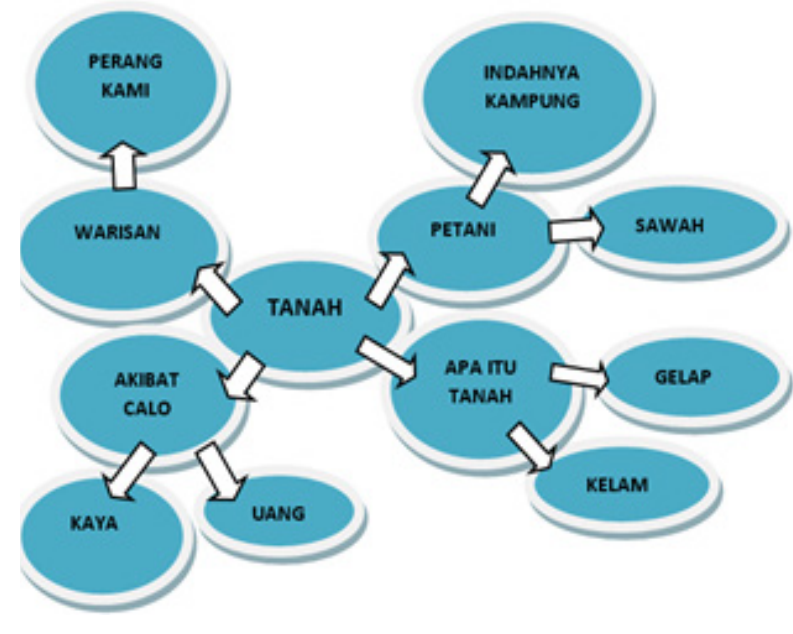

Gambar 2. Konsep Adegan

Sumber: Dokumentasi Peneliti, 2021

Kerangka gagasan atau ide kemudian ditemukan oleh sutradara untuk membangun pertunjukan. Konsep wacana tanah sebagai tema utama kemudian dibagi menjadi beberapa sub-tema yaitu; petani, sawah, dan indahnya kampung; warisan, dan perang kami; akibat calo, kaya, dan uang; apa itu tanah, gelap, dan kelam. Pemaparan sub-tema tersebut ditemukan ketika tema utama dianalisis dan dibagi-bagi seperti ranting pohon. Pembagian tersebut kemudian melahirkan pemikiran-pemikiran dari setiap pemain untuk mengembangkan gagasan agar menjadi kalimat-kalimat yang muncul secara spontan dan komunikatif.

Para penulis yang menjadi pemain ini tidak hanya diajak berimajinasi, tetapi diajak juga untuk mewakili dirinya sendiri, dan mengatakan sesuatu yang mereka setujui. Seluruh komunikasi, kalimat-kalimat itu, paling tidak memiliki dua dimensi: pesan dan isi dimensi serta hubungannya. Kalimat yang dibuat cenderung berkembang di panggung. Para aktor memperjelas dan memberi pengertian ulang tentang apa arti sebuah hubungan, antara dirinya - hidupnya - dan lingkungan sekitarnya. Sehingga pertunjukan akan penuh improvisasi, namun dibatasi tema inti.

\section{Pemain}

Pemain merupakan manusia yang tidak bisa disederhanakan karena dia memiliki kompleksitas psikologi, ketajaman intelektual, 
bahasa tubuh, warna suara, dan budaya yang beragam. Kompleksitas manusia ini kemudian memunculkan keragaman persepsi para pemainnya. Menyamakan persepsi menjadi hal pokok dalam pelaksanaan teater yang bertujuan untuk mengomunikasikan gagasan kepada penonton. Teater tidak hanya milik sutradara, tetapi juga milik pemain, penata artisitik, penata lampu, penata kostum, penata musik, dan seluruh pendukung karya tersebut.

Pemain yang bersifat awam (dia bukan aktor teater), harus melatih tiga hal mendasar yaitu melatih tubuhnya, melatih vokalnya, dan melatih sukmanya. Hal ini penting sebab pemain adalah unsur utama teater. Para pemain harus terus-menerus melatih dirinya dengan banyak pendekatan. Pemain biasanya menyanyi, membacakan puisi, mengucapkan huruf latin, dan huruf hijaiyah untuk melatih vokal mereka. Selain itu, mereka biasanya pencak silat, menari, dan melakukan permainan rakyat untuk melatih tubuh mereka. Mereka juga berlatih membuka kepekaan emosinya untuk melatih sukma dan emosi mereka.

Latihan yang dilakukan dalam proses teater ini biasanya menggunakan pendekatan permainan karena cenderung lebih cepat diserap. Permainan yang dilakukan merupakan permainan yang memerlukan kerja kelompok, bukan yang bersifat kompetisi individu. Permainan yang tidak tepat akan berdampak psikologi yang kurang baik, seperti tidak percaya diri, gelisah, khawatir, dan merasa bodoh. Permainan yang dilakukan hampir sama dengan pendekatan pembebasan tubuh dalam buku Game and Exercise: For Actor and Non-Actor karya Boal (2005).

Selama proses pembentukan teater ini, para pemain tidak boleh menjadi kanvas kosong, karena mereka mempunyai sejarah, mempunyai tubuh sosial, memiliki tarian, nyanyian, impian, dan harapan. Pemain harus ikut menyatakan dirinya di atas panggung, tidak terpaku pada naskah, dan penuh improvisasi. Pengembangan diri para pemain ditumbuhkan melalui fakta bahwa mereka memiliki dimensi tingkah laku yang berlainan, dan mereka harus diajak untuk memahami luasnya cakrawala budaya.

\section{Sutradara}

Sutradara bukanlah satu-satunya pimpinan kerja kreatif, melainkan berbagi peran dengan yang lain. Semakin beragam pembagian peran, maka semakin kaya dan menarik pertentangan dan diskusi yang terjadi. Proses dari tingkat gagasan sampai pertunjukan dilakukan dengan kesadaran potensi para pendukung. Namun, tentu sutradara sebagai pimpinan kreatif teater berperan pula sebagai pengambil keputusan.

Imajinasi sutradara dan pemain digabungkan ketika mereka menafsirkan adegan dalam proses penciptaan sebuah pertunjukan teater. Salah satu cara menafsirkannya adalah melalui sketsa. Hal ini mempercepat ekplorasi adegan, sekaligus untuk memudahkan pengadeganan. Fungsi sutradara adalah pembimbing, teman, dan sahabat bagi para pemain untuk membantu pemain mengekpresikan dirinya dengan kalimat yang mereka buat sendiri dan disusun bersama.

\section{Sketsa tafsir adegan}

Proses lain yang biasa dilakukan adalah dengan menafsirkan adegan melalui sketsa gambar. Sutradara disibukkan dengan coretan-coretan gambar yang menjelaskan adegan demi adegan di atas panggung. Beberapa contoh sketsa saat membuat adegan dibuat sangat sederhana. Cara ini memudahkan komunikasi sutradara dan pemain (terutama untuk anak-anak). Contoh sketsa yang dibuat dalam pertunjukan "Tanah Ode Kampung Kami” adalah gambar adegan yang ditafsirkan dari permainan panjat pinang dan bambu gila, seperti terlihat pada Gambar 3 dan Gambar 4 berikut:

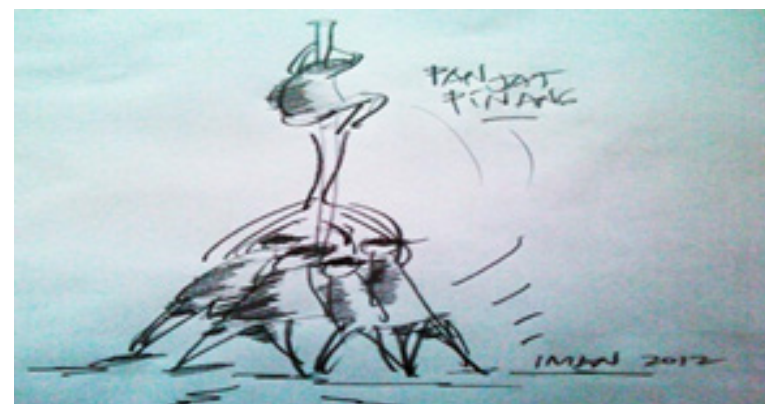

Gambar 3. Sketsa Adegan Panjat Pinang Sumber: Dokumentasi Peneliti 


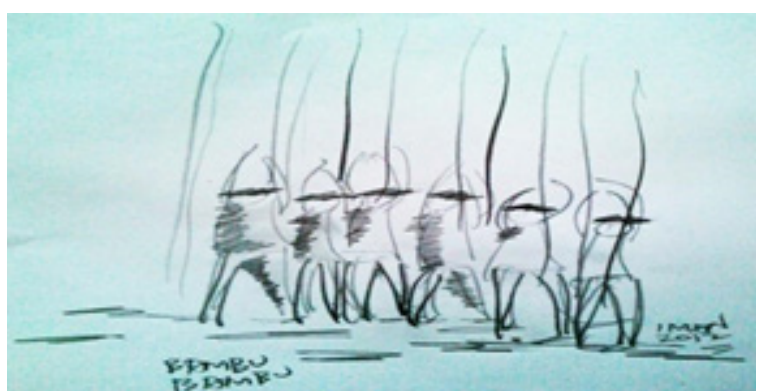

Gambar 4. Sketsa Adegan Bambu-Bambu

Sumber: Dokumentasi Peneliti

\section{Tempat dan artistik panggung}

Pada beberapa tahun terakhir pertunjukan Komunitas CCL selalu memilih tempat di luar gedung. Tempat pertunjukan bukan hanya untuk kebutuhan seni, tetapi juga sangat menentukan keberhasilan sebuah pertunjukan dalam mengomunikasikan konten pertunjukan pada masyarakat. Pertunjukan ini menghindari tontonan yang sekedar tontonan, tetapi gubahan teks mengandung konteks yang dibuat menjadi relevan dengan kondisi yang terjadi di masyarakat.

Sutradara dan penata artistik saling memberi masukan dan bekerja sama untuk kebutuhan pertunjukan. Di dalam hal artistik, penata mempertimbangkan beberapa aspek, yaitu aspek estetik dan aspek guna. Susunan bambu menjadi tempat yang membatasi sekaligus sebagai ruang yang tidak terbatas. Gambar 5 adalah Jebor, pabrik genteng di Jatiwangi, yang merupakan inspirasi pertama dalam penataan artistik panggung, dengan menggunakan ratusan bambu yang tersusun seperti saat pembangunan gedung.

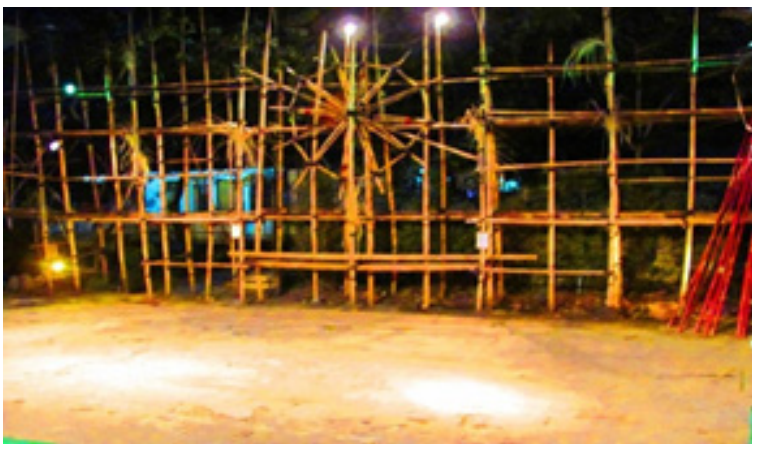

Gambar 5. Artistik Teater

Sumber: Dokumentasi Peneliti
Selain sawah dan ilalang, bambu juga dipilih sebagai identitas desa, karena memiliki sifat sederhana, sekaligus kuat dan guyub (kebersamaan dan satu persepsi). Pemilihan elemen bambu sangat tepat bagi pertunjukan teater ini. Atmosfer tema tanah dan bambu terasa intim satu sama lain.

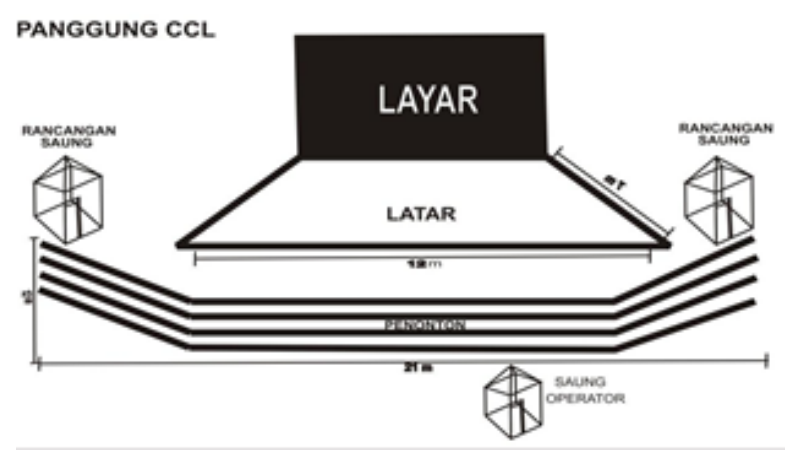

Gambar 6. Tempat Pertunjukan Sumber: Dokumentasi Peneliti

Gambar 6 adalah tempat pertunjukan. Sekeliling tempat pertunjukan menjadi semacam ruang bagi penonton dan pemain. Bambu berbentuk kotak segi-empat berukuran kira-kira $13 \times 16 \mathrm{~m}$ dengan tinggi sekitar $7 \mathrm{~m}$ menjadi begitu megah. Penata artistik memberi judul instalasinya "Kampung dikepung Tamu". Seluruh aspek elemen pertunjukan ini berunsur bambu, termasuk peralatan yang digunakan oleh para pemain. Mempelajari tempat pertunjukan menjadi sangat penting bagi pendukung teater, terutama penata artistik dan sutradara.

\section{Elemen artistik lain}

Elemen-elemen artistik lain untuk kebutuhan para pemain menggunakan barang yang ada di sekitar, terutama peralatan yang digunakan di tanah Sunda. Misal pipiti, yakni sebuah anyaman bambu yang memiliki fungsi sebagai tempat makanan dalam selamatan (biasa dikenal sebagai bésék dalam bahasa Sunda), aseupan, yaitu anyaman bambu berbentuk kerucut yang biasanya digunakan untuk menanak nasi (atau seringkali dikenal dengan istilah 'kukusan'). Seiring dengan pesatnya jaman, pipiti telah diganti dengan kan- 
tong plastik atau gabus, begitu juga aseupan telah diganti magic jar. Pendekatan "badingkut" (barang yang ada diangkut) dilakukan secara maksimal. Barang-barang itu didapat dari teman atau tetangga, baik pada penggunaan alat yang akan dipakai pemain maupun kostum para pemain. Selanjutnya pemilihan benda - benda tersebut dilakukan selektif dan seksama.

Kostum yang digunakan tidak didesain secara khusus seperti pertunjukan drama yang mempertimbangkan waktu-tempat-kejadian. Hal itu cukup dikoordinasikan oleh penata kostum yang melakukan konsultasi dengan pemain mengenai baju yang mereka miliki.

Begitu pun dengan penataan cahaya, cukup sekedar membangun suasana saja, seringkali tidak ada identitas waktu berupa siang atau malam. Cahaya panggung menggunakan lampu yang dibuat sendiri dari kaleng-kaleng besar, dan lampu standar pencahayaan taman 120 Watt milik Komunitas CCL Bandung.

Setelah semua alat dan barang yang diperlukan telah lengkap, kemudian konsep digagas secara utuh hingga menjadi pertunjukan teater yang disaksikan oleh banyak orang. Pesan yang disampaikan dalam pertunjukannya masih memerlukan evaluasi sebagai tolak ukur usaha yang telah dilakukan dalam proses penciptaan teater "Tanah Ode Kampung Kami".

\section{Metode Penulisan Naskah}

Berbeda dengan kelompok teater pada umumnya, Komunitas CCL Bandung memiliki gaya tersendiri dalam mementaskan pertunjukan teater. Perbedaan paling signifikan dapat ditemukan pada naskah yang dipentaskan, yang merupakan hasil pemikiran tiap aktor. Metode ini dikenal sebagai pembuatan teks secara bersama-sama atau naskah kolektif dan dipraktikkan guna meningkatkan kemampuan aktor dalam menulis (writing). Setiap aktor di Komunitas CCL Bandung diwajibkan untuk berlatih menulis naskah sendiri, selain mengolah kemampuan (skill) lain seperti menari (dancing), bernyanyi (singing), dan bermain peran (acting).

Proses kepenulisan naskah tersebut dapat dipahami pada Bagan 1 berikut:

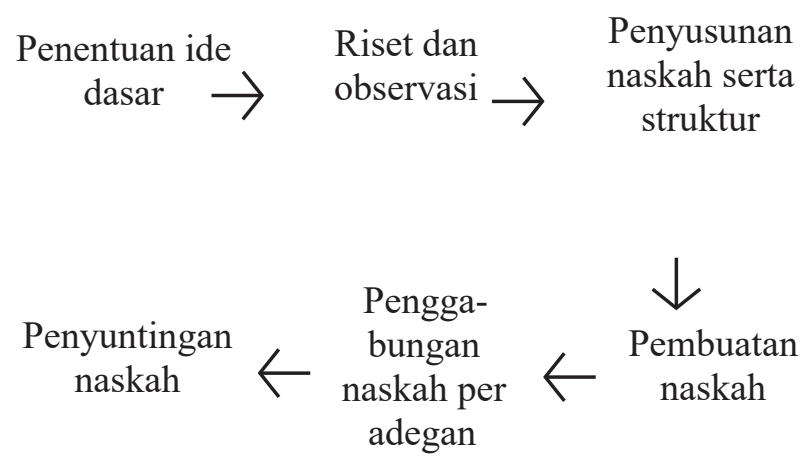

Bagan 1. Tahapan Proses Kepenulisan Naskah

Sumber: Dokumentasi Peneliti

Tahapan pertama yang dilakukan adalah penentuan ide dasar yang dilakukan secara bersama-sama, dari mulai permasalahan yang khusus membahas pemberdayaan masyarakat. Tahapan kedua adalah riset dan observasi yang dilakukan oleh aktor dan sutradara. Teknik pengumpulan data yang dilakukan yaitu observasi dan wawancara. Sebagai hasil observasi, sutradara dan aktor mengamati dan terlibat langsung dengan aktivitas petani di Lembang, Kabupaten Bandung Barat, Jawa Barat sehingga mereka mendapatkan gambaran untuk tahapan selanjutnya.

Selain observasi, para penulis menggunakan teknik wawancara untuk mendapatkan data dari informan. Wawancara digunakan untuk memperoleh data dalam permasalahan tanah. Permasalahan tersebut kemudian didiskusikan dengan sutradara hingga terbentuk sebuah naskah dengan pedoman sebagai bahan untuk mendapatkan data yang lengkap. Para penulis naskah juga menggunakan kamera digital atau kamera gawai, dan perekam suara. Penggunaan alat tersebut bertujuan agar data dari informan bisa didapat dengan lengkap. Selanjutnya, penulis mengimplementasikan hasil riset tersebut menjadi naskah teater berjudul "Tanah Ode Kampung Kami”. Para penulis juga mencari simbol-simbol di dalam budaya yang termasuk kategori (domain) yang lebih besar berdasarkan hal yang diperlukan dalam pembuatan nas- 
kah teks kolektif.

Setelah itu, dilakukanlah proses penciptaan naskah teater bersama dengan data yang dimiliki. Pemikiran-pemikiran yang ditemukan di lapangan dapat lebih selaras ketika penemuan dilakukan secara bersama-sama. Sumber-sumber dari riset tersebut berupa informasi yang didapat melalui wawancara kepada para petani, studi literatur, tulisan media cetak, televisi, serta mengadakan diskusi terbuka terkait lingkungan hidup, dan UU Agraria.

Setiap aktor ketika mulai mengumpulkan data dan menyusun naskah tidak melepaskan identitas atau pengalaman-pengalaman yang mereka dapat. Semuanya memiliki sejarah masing-masing yang dapat dituliskan dan menjadi data autentik pertunjukan. Di antara para aktor, terdapat pula beberapa orang yang memiliki latar belakang bertani, hidup di lingkungan desa, dan orang yang kehidupannya mengalami peralihan dari desa menuju kota. Pengalaman merupakan salah satu dari sekian informasi dan data yang digunakan dalam penyusunan naskah kolektif. Pengalaman masing-masing para aktor menghadirkan spontanitas dalam pertunjukan yang bersifat koheren dengan gagasan. Ketika naskah telah selesai disusun, para aktor akan lebih mudah untuk mengembangkan teksnya sendiri karena pengalaman yang dimilikinya.

Tahapan ketiga adalah pembuatan naskah pertunjukan. Pembuatan naskah teater diarahkan langsung oleh sub-tema yang telah ditentukan sutradara. Peran penting dari sutradara adalah membantu para aktor untuk saling mengolah dialognya secara reaksioner atau spontan. Munculnya dialog-dialog yang berkaitan dengan gagasan utama terkait tanah dalam pembuatan naskah pertunjukan, didukung oleh riset yang sebelumnya telah dilakukan.

Sutradara sebagai sosok yang berperan penting dalam mengarahkan (directing), perlu memberikan ketentuan-ketentuan dalam menghadirkan sub-tema yang nantinya menjadi adegan. Pada adegan "Mereka Datang ke Tanah Kami”, terdapat sembilan aktor yang mengisi dialog. Terdapat ketentuan yang menyatakan bahwa setiap aktor dalam adegan tidak boleh menjalankan lebih dari tiga dialog. Hal tersebut dilakukan untuk mengurangi potensi dialog yang keluar dari gagasan, menghadirkan sifat spontanitas lebih kuat, menambahkan bocoran teks menjadi lebih mudah, serta memperhitungkan durasi dari pertunjukan dan waktu per adegan.

Tidak hanya sutradara, para aktor pun harus memperhatikan ketentuan tersebut. Ketika menyusun naskah, gagasan harus berada di dalam lingkaran tersebut. Kreativitas aktor dalam tahap pembuatan naskah diolah lebih jauh, sehingga aktor tidak hanya memiliki keahlian mengolah peran dan menyutradarai, tetapi juga dapat menuliskan naskah.

Para aktor sebagai penutur folk song dan folk poem harus memiliki kedekatan dengan setiap teks yang dibicarakannya. Tahap pembuatan naskah ini merupakan tahap kedua setelah riset, bagi para aktor untuk melakukan pendekatan pada folk song dan folk poem yang dihadirkan sutradara sebagai bocoran teks. Contohnya colenak yang merupakan folk song menjadi bocoran teks di salah satu adegan pertunjukan. Sebagian aktor sebelumnya tidak mengenali folk song berjudul colenak. Peran sutradara sangat penting untuk lebih mengetahui isi dari lagu, lalu dikaitkan secara teks dan konteks pada pertunjukan yang dibuat. Hal ini berfungsi agar para aktor dapat lebih memahami folk song yang digunakan dalam pentas.

Tahapan keempat adalah penggabungan sub-tema yang digunakan dalam adegan-adegan pertunjukan. Tahap penggabungan sub-tema sangat ditentukan oleh sutradara sebagai penyusun konsep utama. Pertunjukan ini menitikberatkan pada wacana-wacana seperti kasus tanah dan orientasi tradisi. Imaji sutradara sangat digunakan dalam merancang pertunjukan. Imaji ini berfungsi untuk memperhitungkan pencarian serta eksplorasi adegan dalam menggambarkan konsepnya agar lebih mudah dalam mengeksekusi konsep.

Peneliti yang menempatkan diri sebagai 
sutradara dalam pertunjukan ini menyadari bahwa seni teater adalah "sekumpulan bentuk-bentuk seni yang dikumpulkan menjadi satu." Seni teater memiliki unsur sastra, seni rupa, seni tari, seni musik, bahkan fesyen (fashion). Semua unsur memiliki keterkaitan dan saling mendukung untuk mengembangkan diri. Maka dari itu, sutradara perlu memikirkan konsep penataan adegan secara matang ketika penggabungan adegan. Tafsir teks dilakukan tidak terlalu rumit dengan penekanan yang ditunjukan kepada penonton agar dapat lebih memahami apa yang ingin disampaikan oleh pertunjukan.

Penggabungan sub-tema atau adegan yang ada tidak membuatnya rapi dan tersusun. Adegan yang telah tersusun masih mungkin mengalami perubahan dan dipindahkan sesuai konsep pertunjukan. Setiap adegan yang dihadirkan bukan berarti hanya menghadirkan aktor-aktor dari kelompok sub-tema atau adegan tertentu saja. Konsep pertunjukan akan menentukan bagaimana aktor-aktor yang berada di luar kelompok sub-tema untuk berada dalam satu adegan bersama atau tidak. Kerja sama dalam pertunjukan itu sangat penting, karena pengembangan adegan-adegan ditentukan oleh aktor. Sutradara tidak membentuk aktor terlalu jauh, agar identitas dan bentuk dari apa yang dimiliki aktor tetap terjaga.

Langkah selanjutnya setelah penggabungan adalah penyuntingan. Langkah penyuntingan ini merupakan tahap terakhir dari penyusunan naskah kolektif. Tahap berikut dapat berlangsung berkali-kali sampai konsep dari sutradara dirasa sudah tercapai secara tekstual; sub-teks, penempatan atau pemakaian kata, dan penyuntingan atau penghapusan dari kalimat. Fungsi utama dari keempat aspek tersebut adalah agar dialog para aktor lebih komunikatif dan memerhatikan penonton yang tidak semuanya merupakan orang-orang pemerhati seni. Target utama dari pertunjukan ini adalah orang-orang yang sebelumnya tidak memahami pertunjukan teater, yaitu petani, pemerhati lingkungan, barulah kemudian pada pelajar dan mahasiswa.

Proses penyuntingan bisa kembali dilakukan setelah pentas pertunjukan. Tindakan spontanitas terhadap dialog aktor, acap kali menjadi improvisasi ketika pertunjukan. Karena improvisasi tersebut, maka diperlukan adanya revisi ulang terhadap naskah. Ketika pertunjukan teater dipertontonkan, banyak dialog yang diimprovisasi para aktor sehingga terdapat perbedaan cukup signifikan dengan naskah aslinya. Semua poin tersebut akan dibahas dari sisi bagaimana proses terciptanya naskah ketika penyutradaraan pertunjukan "Tanah Ode Kampung Kami” sampai menemukan titik gagasan dan penyuntingan teks.

\section{Simpulan}

Metode yang digunakan dalam pembuatan naskah teater "Tanah Ode Kampung Kami" adalah naskah kolektif, yaitu berupa naskah hasil rembukan aktor dan sutradara yang memiliki berbagai latar belakang yang berbeda-beda. Metode ini digunakan untuk menyelaraskan gagasan yang dibangun secara bersama-sama. Bentuk kerja sama yang dilakukan adalah menyusun naskah pertunjukan hingga menjadi sebuah naskah utuh hasil kolaborasi pemikiran antarunsur yang terdapat di dalam proses pembuatan naskah teks teater. Kolaborasi ini mencakup penentuan ide dasar, riset dan observasi, penyusunan naskah serta struktur, pembuatan naskah, penggabungan naskah peradegan, dan penyuntingan akhir. Seluruh proses ini tidak terlepas dari latar belakang aktor dan seniman yang berbeda-beda, sehingga, ketika perbedaan tersebut dipertemukan dan diselaraskan, akan menghasilkan pementasan teater yang berkualitas. Penulisan naskah kolektif ini menjadi suatu ciri khas bagi kelompok teater independen seperti Komunitas CCL Bandung yang lebih banyak berperan melakukan kritik sosial dalam karya-karyanya.

\section{Daftar Pustaka}

Aaron, J. (2018). Anthropology and Theatre. Performing Arts Journal, 3(3), 100. https://doi. org $/ 10.2307 / 3245108$

Ahimsaputra, H. S. (2002). Wacana Seni dalam Antropologi Budaya, Tekstual, Kontekstual, dan Post Modernitis. Dalam Ketika Orang Jawa Nyeni. Yogyakarta: Galang Press, 399- 
432.

Anirun, S. (2002). Menjadi Aktor (Pengantar Kepada Seni Peran untuk Pentas dan Sinema). Rekamedia Multiprakarsa.

Beeman, W. O. (2017). The Anthropology of Theater and Spectacle Author (s). Annual Review of Anthropology, 22(1993), 369-393.

Blanes, R., Flynn, A., Maskens, M., Tinius, J. (2016). Micro-Utopias: Anthropological Perspectives on Art, Relationality, and Creativity. Cadernos de Arte e Antropologia, 5(1), 5-20. https://doi.org/10.4000/cadernosaa. 1017

Boal, A. (2005). Games for Actors and Non-Actors. In Games for Actors and Non-Actors. https://doi.org/10.4324/9780203994818

Boal, A. (2008). Theatre Of Oppressed. London: Pluto Press.

Broth, M. (2011). The Theatre Performance as Interaction between Actors and Their Audience. Nottingham French Studies, 50, 113-133. https://doi.org/10.3366/nfs.2011-2.006

Butcher, K., Pearce, G., Ross, D. (2017). Using Educational Drama to Teach Investments Management: Evidence of Cross-Cultural Relevance from Australia and China. International Jour-nal of Management Education, 15(1), 67-83. https://doi.org/10.1016/j. ijme.2017.01.005

Conquergood, D. (1985). Performing as a Moral Act: Ethical Dimensions of the Ethnography of Performance. Literature in Performance, 5(2), 1-13. https://doi. org/10.1080/10462938509391578

de Goulart, B. N. G., and Vilanova, J. R. (2011). Professional Theatre Actors: Environmental and Socioccupational use of Voice. Jornal Da Sociedade Brasileira de Fonoaudiologia, 23(3), 271-276. https://doi.org/10.1590/ S2179-64912011000300014

Doyin, M. (2001). Masalah Keaktoran dalam Teater Modern. Harmonia - Journal of Arts Research and Education, 2(3), 21-28.

Elam, K. (1977). Language in the Theater. SubStance, 6(18/19), $139 . \quad \mathrm{https} / /$ doi. org/10.2307/3683990

Emenike, E. (2017). The Actor, the Director and the Playwright: In Search of the Master Artist. MAJAC: Makurdi Journal of Arts and Cultures, 14(1).

Enria, L. (2016). Co-producing Know-ledge Through Participatory Theatre: Reflections on Ethnography, Empathy and Power. Qualitative Research, 16(3), 319-329. https://doi. org/10.1177/1468794115615387

Eny Iryanti, V. (2016). Kenikmatan Estetis dalam Seni Suatu Tinjauan Filosofis. Imaji, 14(2), 139-145. https://doi.org/10.21831/imaji. v14i2.12177

Fabian, J. (1999). Theater and Anthropology, Theatricality and Culture. Research in African Literatures, 30(4), 24-31. http://www.jstor. org/stable/3820750

Fons Sastre, M. B. (2019). Investigating the Actor's Dramaturgy: Theatre Anthropology and its Scientific Applications. Revista Brasileira de Estudos Da Presença. Brazilian Journal on Pre-sence Studies, 9(3), 1-27. https://doi.org/10.1590/2237-266089715

Gasani, M. El. (2019). Pemberdayaan Masyarakat melalui Kegiatan Seni di Komunitas Celah-Celah Langit (KCCL). Umbara, 4(1), 1. https://doi.org/10.24198/umbara.v4i1.22415

Gill, C. (2013). Enhancing the English-Language oral skills of international Students Through Drama. English La-nguage Teaching, 6(4), 29-41. https://doi.org/10.5539/elt.v6n4p29

Goodlander, J. (2012). Gender, Power, and Puppets: Two Early Women Dalangs in Bali. Asian Theatre Journal, 29(1), 54-77. https:// doi.org/10.1353/atj.2012.0013

Grimshaw, A., and Ravetz, A. (2015). The Ethnographic Turn - and After: A Critical Approach towards the Realignment of Art and Anthropology. Social Anthropology, 23(4), 418-434. https://doi.org/10.1111/14698676.12218

Gualdron, E., and Castillo, E. (2018). Theater for Language Teaching and Learning: The E Theater, a Holistic Methodology. Profile: Issues in Teachers' Professional Development, 20(2), 211-227. https://doi.org/10.15446/profile.v20n2.63969

Harymawan, R. (1988). Dramaturgi. Remaja Rosdakarya.

Hayes, E. C. (1911). The Classification of Social Phenomena. American Journal of Sociology, 17(2), 188-205. http://www.jstor.org/stable $/ 2762947$

Hulse, B., and Owens, A. (2019). Process Drama as a Tool for Teaching Modern Languages: Supporting the Development of Creativity and Innovation in Early Professional Practice. Innovation in La-nguage Learning and Teaching, 13(1), 17-30. https://doi.org/10.1 080/17501229.2017.1281928

Jelinek, A. (2016). An Artist's Response to an Anthropological Perspective (Grimshaw and 
Ravetz). Social Anthropology, 24(4), 503-509. https://doi.org/10.1111/1469-8676.12344

John, P. St. (1992). The Aesthetic Experience: An Anthropologist Looks at the Visual Arts. Art Therapy, 9(4), 203-206. https://doi.org/10.10 80/07421656.1992.10758964

Knight, D. M., and Stewart, C. (2016). Ethnographies of Austerity: Temporality, Crisis and Affect in Southern Europe. History and Anthropology, 27(1), 1-18. https://doi.org/10.10 80/02757206.2015.1114480

Koentjaraningrat. (2015). Pengantar Antropologi. Rineka Cipta.

Lemon, A. (2004). Dealing Emotional Blows: Realism and Verbal "Terror" at the Russian State Theatrical Academy. Language and Communication, 24(4), 313-337. https://doi. org/10.1016/j.langcom.2004.01.001

MacKey, S. (2007). Performance, Place and Allotments: Feast or Fa-mine? Contemporary Theatre Review, 17(2), 181-191. https:// doi.org/10.1080/10486800701234457

Maihoub, A. (2015). Thinking Through the Sociality of Art Objects. Journal of Aesthe-

tics and Culture, 7. https://doi.org/10.3402/ jac.v7.25782

Mauro, K. (2017). The Realistic Acting Method as a Mechanism of Attenuation of the Actor's Presence in Theatre and Cinema. Rev. Bras. Estud. Presença, Porto Alegre. Brazilian Journal on Presence Studies, 7(3), 523-544.

Miccoli, L. (2003). English Through Drama for Oral Skills Development. ELT Journal, 57(2), 122-129. https://doi.org/10.1093/elt/57.2.122

O’Donnell, D. (2017). Spiritual Play: Ritual Performance and Spirituality in Samoan Theatre. In J. Cattermole and H. Halba (Eds.), Ritual and Cultural Performance (pp. 27-40).

Raquel, M. R. (2011). Theatre Production as a Language Learning Environment for Chinese Students. The Journal of Drama and Theatre Education, 2(1), 93-120.

Schneider, J., Lowe, S., Myers, T., Scales, K., Bailey, S., and Middleton, J. (2014). A Short Report on Knowledge Exchange Through Research-based Theatre: Inside Out of Mind. Social Science and Medicine, 118(C), 61-65. https://doi.org/10.1016/j. socscimed.2014.07.049

Simonović, A., S., and Alifirević, Đ. (2017). Performance Studies as New Anthropology of Events. AM Journal of Art and Media Studies, 12, 149. https://doi.org/10.25038/ am.v0i12.174

Suharianto, S. (1982). Berkenalan dengan Cipta Seni. Mutiara Permata Widya.

Sumardjo, J. (2001). Seni Pertunjukan Indonesia. STSI Press.

Todorov, T. (1985). Tata Sastra. IKAPI.

Turner, V. (1979). Frame, Flow and Reflection: Ritual and Drama as Public Liminality. Japanese Journal of Religious Studies, 6(4), 465-499. http://www.jstor.org/stable/30233219

Waterson, R. (2010). Testimony, Trauma and Performance: Some Examples from Southeast Asian Theatre. Journal of Southeast Asian Studies, 41(3), 509-528. https://doi. org/10.1017/S0022463410000287

Wessels, A. (2014). Greenbelt or Gutter: Youth "Place-based" Performance and the Myth of the Suburban/Urban Divide. Research in Drama Education, 19(1), 76-88. https://doi. org/10.1080/13569783.2013.872434

Wilkinson-Weber, C. M. (2012). An Anthropologist Among the Actors. Ethnography, 13(2), 144-161. https://doi. org/10.1177/1466138111413336

Yalouri, E. (2016). The Metaphysics of the Greek Crisis: Visual Art and Anthropology at the Crossroads. Visual Anthropology Review, 32(1), 38-46. https://doi. org/10.1111/var.12091 